\title{
Journal of Sustainability Perspectives
}

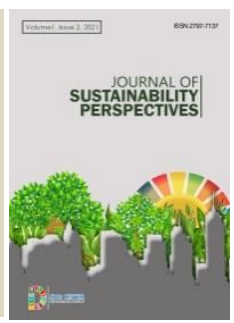

\section{IPB University's Policy of Biodiversity's Innovation for Eco- Edutourism}

\author{
Arif Satria ${ }^{* 1}$, Aceng Hidayat ${ }^{2}$, Abdul Haris Mustari $^{3}$ \\ ${ }^{1}$ Department of Science for Communication and Community Development, Faculty of Human Ecology, IPB \\ University, Indonesia. \\ ${ }^{2}$ Department of Resources and Environmental Economics, Faculty of Economics and Management, IPB \\ University, Indonesia. \\ ${ }^{3}$ Department of Forest Resources Conservation and Ecotourism, Faculty of Forestry, IPB University, Indonesia. \\ *corresponding author: arifsatria@apps.ipb.ac.id
}

\section{Article Info}

Received:

15 March 2021

Accepted:

25 May 2021

Published:

1 June 2021

DOI:

https://doi.org/10.14710/i sp.2021.11748

\begin{abstract}
IPB University has declared as a Biodiversity Campus since 2011. This declaration was carried out considering the high biodiversity at the IPB University Campus. One of the causes of the high campus biodiversity is the uniqueness of the campus landscape and the maintained proportion between the built and open-green areas. The existence of lakes, forests, arboretums, plantations, and three rivers that cross the campus area has contributed to the high diversity of habitats and consequently to the biodiversity. At least 22 species of mammals, 99 species of birds, 12 species of amphibians, 38 species of reptiles, 128 species of butterflies, 173 species of woody-plants, 40 species of bamboos and 127 species of medicinal plats have been recorded inhabiting the 257 ha of the campus area. The biodiversity has significant role as objects for research of the students, lecturers, researchers as well as for tourism such as for bird watching, picture hunting, outbond and other recreational activities. Therefore the campus functions for education and for tourism, thus ecoedutourism for academic community as well as community around the campus. To maintain the biodiversity, IPB University issued several policy innovations. The first policy innovation is monitoring of population and distribution of biodiversity on a regular basis. Second, habitat management for biodiversity. Third, on-site and offsite socialization to campus and offcampus communities. Fourth, conserving the habitats of the flora and fauna. Fifth, rare tree planting. Sixth, the movement to plant fruit trees by each faculty. Seventh, conservation of biopharmaceutical medicinal plants. Eighth, building a garden for food sovereignty. Ninth, conducting research on campus biodiversity. All of these policies involve the academic community, experts, alumni and the community around the campus.
\end{abstract}

\section{Keyword:}

biodiversity, eco-edutourism, IPB University, policy

\section{Introduction}

IPB University green campus has five pillars: 1) Mintaining biodiverity, 2) Efficiency in 
air, 3) Efficiency energy, 4) Integral waste management, and 5) Environment-friendly campus transportation. Biodiversity covers all living organisms of flora and fauna which is the most important component of a green campus. Biodiversity is fundamental of a green campus that serves convinient atmosphere for the campus community including lecturers, students, and the academic supporting staffs. IPB University campus in Dramaga covers an area of $257 \mathrm{ha}$, which is one of the biggest campus area in this country. Two-third of the 257 total campus area is green area, and it is the strong commitment of the campus community to conserve its biodiversity. The green areas have facilitated suitable habitats for many species both wildlife and plant [5].

Historically, the landscape of this campus was once dominated by rubber plantation (Hevea brasiliensis) untill 1940s, yet the plantation was slowly replaced with other species in line with the campus develompment. However, scattered of rubber stands could still be found around the campus, including old rubber trees of more than 50 years old. Its topography varies from relatively flat at the eastern and southern parts undulated at the western and northern areas, providing a spectacular and unique landscapes. Addditionally, the campus landscape is surrounded by three beautiful rivers namely Ciapus, Cihideung, and Cisadane at the north, east and west campus borders respectively. These all year round rivers have become centres of biodiversity of the fresh water aquatic-species and for terrestrial and arboreal species inhabiting along of the riverine habitats.

Habitat and landscape of the campus is now dominated by arboretums of faculty of forestry, arboretum of bamboo, arboretum of landscape architecture, nursery centre, old and new plantations, cultivation area, forests, medicinal plants, animal husbandry and veterinary field laboratories, lakes and fish ponds of the faculty of fishery and marine science. Outside of the campus enclosure, IPB University also has paddy field, plantation, animal husbandry. The campus also has Gunung Walat Educational Forest located in Sukabumi Regency, West java, which one of the best educational forests that frequently visited by students and researchers from other universities studying forestry and biodiversity. Thus, IPB University campus is frequently used as a bencmark model for developing an educational forest.

Biodiversity is strongly related with diversity of habitats. Diversity of plants, ecosystem, landscape inside of the campus are key factors determining the biodiversity richness. The higher the habitat diversity the higher the wildlife diversity. Based on the high divesity of flora and fauna, and the uniqueness of the campus landscape, IPB University has strong commitment to maintain the variety of the habitats to conserve the biodiversity. This paper aims to analyze the IPB innovative policies in developing eco-edutourism in relation with the campus biodiversity. The following are the IPB University policies in addressing the campus biodiversity.

\section{Biodiversity's Innovation for Eco-Edutourism}

Eco-Edotourism plays an important role in raising awareness of green campus development, motivating people to conserve environment, and teaching the importance of conserving biodiversity for human livelihood. It provides economic, social and cultural incentives for the academic community while staying an environmentally friendly way to conserving high biodiversity value consistent with commitments to nationally determined contributions (NDCs), Convention on Biological Diversity (CBD), Convention on International Trade in Endangered Species of Wild Fauna and Flora (CITES), Millienium Development Goals 
(MDGs), Sustainable Development Goals (SDGs), among others. To maintain biodiversity and Eco-Edutourism, IPB University issued several policy innovations.

\subsection{Monitoring of population and distribution of biodiversity on a regular basis}

The biodiversity monitoring has been conducted during the last 20 years in the campus area. The monitoring covered habitat types, list of species and distribution of all taxa including mammals, birds, amphibians, reptiles, butterflies and plants. The long-term biodiversity monitoring has produced a comphrehensive data set and a list of flora and fauna in the campus area that is updated every year. A total of 22 species of mammals, 99 species of birds, 12 species of amphibians, 38 species of reptiles, 128 species of butterflies, 173 species of woody-plants, 40 species of bamboos and at least 127 species of medicinal plants have been recorded in IPB University campus area $[1,2,3,4,5]$. The woody-plant species recorded in this campus covering many families including Dipterocarpaceae, Ebenaceae, Lauraceae, Fabaceae, Annonaceae, and Moraceae.

\subsection{Habitat management for biodiversity}

IPB University campus has many habitat types and unique landscape. There are many habitat types including arboretums dominated by woody-plants with multy-layer canopies, grassy areas, lakes, swamps, tributaries, riverine forests, plantations, bamboos, and green are among of the built areas, all of which are suitable for biodiversity, combinations of many habitats types covering terrestrial and aquatics. These habitats are in flat and rugged landscapes that optimize the habitat function and hence the variety of flora and fauna. The habitats have provide foods, water and shelters for the wildlife and biodiversity. IPB University has high commitments to maintain the habitats as natural as possible by facilitating natural succession of the ecosystem. Some of the habitats are enriched with plant species collected from many parts of Indonesia. Thus, the habitats function not only for the wildlife but also as educational arboretums.

\subsection{On-site and offsite socialization to campus and off-campus communities}

The dissemination of information and socialization of the campus biodiversity are key factors determining people awareness and conservation of biodivesity. Through the socialization, the eco-edutourism activities could be promoted. The socialization has been conducted on-site and off-site and off-campus communities including students, school children, and communities from different background. The effective media such as laflets, booklets, campus biodiversity documentary films are produced. Through the media and the continuous socialization, people awareness could be gradually increased, they would appreciate the nature and finally, they would conserve biodiversity in sustainable way.

\subsection{Conserving the habitats of the flora and fauna}

Biodiversity of flora and in the campus are maintained by conserving the essential habitats for biodiversity, both natural and man-made habitats. The natural habitats include the riverine forests, lakes, and swamps around the campus, whereas the man-made habitats cover the plantations and plantations surrounding of the buildings, arboretums, etc. The essesntial habitats have been plotted and dileniated as part of IPB University Blue Print longterm development. These habitats would be consistently protected as green area. IPB University has high commitment to conserve the these habitats by minimizing disturbance and negatif impacts. This policy also include the development of an integrative waste 
management, separating organic and an-organic materials. The organic materials have been recycled into compous.

\subsection{Rare-tree planting.}

There are several aboretums in the campus aimed to collect plant species from many parts of this country. The rare tree such as iron wood (Eusiderexylon zwageri), eboni (Diospyros celebica), Shorea spp., Intsia bijuga, could be found mainly in arboretums of faculty of forestry, arboretum of landscape architecture, arboretum of Cikabayan, and the old vegetation surrounding the Alhurriyah Mosque. A total of 40 bamboo species could be found in the arboretum that specifically built for bamboo species collected from all over Indonesia.

\subsection{The movement to plant fruit-trees by each faculty.}

This policy aimed to increase diversity of flora as well as providing suitable habitat for wildlife. By growing fruit-trees the green area in campus would be increased. The edible fruit-trees such as Durio zibethinus, Pangium edule, Psidium guajava, Pometia pinnata, Antidesma bunius, Arenga pinnata, Inocarpus fagifer, Artocarpus integra, Canarium commune have been planted surrounding the campus area.

\subsection{Conservation of biopharmaceutical medicinal plants.}

The biopharmaceutical medicinal plants is in the western part of the IPB University campus, consisting 127 species of medicinal plants [5]. The medicinal plants were collected from many parts of Indonesia and were cultivated in campus area. The medicinal plants are managed by division of Medicinal Plant Conservation Unit of IPB University, aimed to study, to use and to conserve the high variety of medicinal plants of Indonesia. The medicinal plants have been functioned as field laboratory for students and researches, and frequently visited by communities, school children, students from other universities learning medicinal plants and/or doing comparative studies, which is part of eco-edutourism. They learn medicinal plants including species, useful, and traditional wisdom of Indonesian people in using these medicinal plants.

\subsection{Garden for food sovereignty.}

Gardens for food sovereignty have been developed surrounding the area, both monoculture and heteroculture systems. Gardens of cassava, corn, paddy field, and fruittrees have multi-purposes as for food supply, field laboratoriums, maintaining biodiversity, creating better micro climate, and as part of ec-edutourism. The animal husbandry has been also developed as part main components of food sovereignity.

\subsection{Conducting research on campus biodiversity.}

IPB University's students, lecturers and researchers have been using biodiversity in the campus as important objcts for doing research that cover disciplines of both botany and zoology. These research topics include taxonomy, ecology, behaviour, wildlife inventory, wildlife management, entomology, These topics cover taxa of mammals, birds, amphibians, reptiles, butterfiles, medicinal plants, aquatic animals in the lakes, ponds, and rivers. Students are encouraged to conduct researchs on campus, exploring the high biodiversity and publishing their research on journals. 


\section{Conclusion}

Bogor Agricultural University campus is rich in biodiversity. IPB University biodiversity's innovative policy ensuring that the diversity of flora and fauna in the campus would bbe managed and sustainably used for the sake of the campus communities and of the biodiversity conservation. These policy included monitoring of population and distribution of biodiversity on a regular basis, habitat management for biodiversity, on-site and offsite socialization to campus and off-campus communities, conserving the habitats of the flora and fauna, rare tree planting, the movement to plant fruit trees by each faculty, conservation of biopharmaceutical medicinal plants, building a garden for food sovereignty, and conducting research on campus biodiversity.

\section{References}

1. Mustari, A.H., 2011. Panduan lapang Mamalia di Kampus IPB Dramaga. IPB Press.

2. Mustari, A.H., 2014. Mengenal Amfibi dan Reptil Kampus IPB Dramaga. IPB Press.

3. Mustari, A.H., Gunadharma, N., 2016. Kampus Biodiversitas: Kupu-kupu di Wilayah Kampus IPB Dramaga. IPB Press.

4. Mustari, A.H., 2018. Biodiversitas Kampus IPB Dramaga, Bogor:mamalia,burung,amfibi, reptil, kupu kupu dan tumbuhan. IPB Press. 